\title{
The Land Rights of Indigenous Peoples: Revaluation of Papua Special Autonomy
}

\author{
Eddy Pelupessy \\ Faculty of Law, Cenderawasih University \\ Jln. Kamp. Wolker, Waena, Jayapura, 99358, Papua, Indonesia \\ Tel./Fax: +62-967-585470 E-mail:e pelupessy@yahoo.com \\ Submitted: Feb 16, 2017; Reviewed: Mar 28, 2017; Accepted: Mar 29, 2017
}

\begin{abstract}
The purpose of Special Autonomy for Papua is to resolve the source of the problem in Papua, especially concerning the rights of indigenous peoples. Normatively, the background of local autonomy for Papua is affirmed in Act No. 21 of 2001 on Papua Special Autonomy. The results shows that the recognition and protection of the land rights of indigenous peoples have been set clearly in the national legal system, such as Agrarian Law, Forest Law, as well as in Mineral and Coal Mining Law. However, recognition and protection of indigenous peoples'rights to land in various legal products is still ambivalent. The essence of protection of indigenous peoples' rights to land is also clearly regulated in Act No. 21 of 2001 and Perdasus No. 23 of 2008 has put customary law community on ownership of communal land is not the object of development, especially in the field of investment. The customary right and indigenous land which is the property and become an authority on indigenous peoples must be recognized by the government and regional and national communities about its presence. Therefore, the government should strive to protect the customary right through regulation of the Ministry of Agrarian and Land Agency and other laws related to the issue of customary rights, customary lands, indigenous peoples and their authority.
\end{abstract}

Keywords: Customary Law; Indigenous Peoples; Land Rights; Special Autonomy

DOI: 10.20956/halrev.v3i1.1047

\section{INTRODUCTION}

The concept of special autonomy is selected as response for development gap that occurs in Papua and other regions in Indonesia. The special autonomy begins known in Indonesian government system in reform era. Previously, it is only known the term "Special Region" and "Extraordinary Region". ${ }^{1}$ The

Article 18 the 1945 Constitution before amendment states, "region division of Indonesia based on large and small regions, with the form of administration structure is determined based on legislation, by looking and remember the basic of parley in the national administra- presence of special autonomy is a part of political reversal of governance that initially as centralistic and uniform towards decentralization and appreciation to diversity. It is aligned with democratization as main path of reform. Democratization of governance demanded decentralization and respect for regional diversity.

In view from socio-economic, centralization that has practiced during the New

tion, and the rights of regions origin are special." 
Order era has emerged a gap of central and local, as well as disparities inter-region, and led to the threats of national integration. Decentralization in local is expected to realize relations between centre and local are more just and democratic. Especially for Aceh and Papua, the special autonomy is also expected to resolve the conflict of integration that has prolonged.

Normatively, the background of local autonomy for Papua is affirmed in Act No. 21 of 2001 concerning Papua Special Autonomy (hereinafter abbreviated Special Autonomy Act for Papua). General explanation of Act No. 21 of 2001 describes that the granting of special autonomy for Papua is motivated by State recognition for 2 (two) important things: First, the government recognizes since the establishment of these Act, there are a problem in Papua and not yet solved. The problems includes political, government, economics, and social and culture; Second, the government recognizes that there are a mistake in policy as taken and implemented to resolve various problems in Papua. It is known explicitly that what implemented in Papua is not fulfilled the sense of justice, not enables the achievement of welfare, law enforcement, and respect against human rights, particularly for Papua peoples.

On the other hand, it also recognized that the management and utilization of natural wealth is not used optimally to improve the life of native communities so it resulted in gaps both between Papua peoples and Papua with other region in Indonesia. It happened because of past policy is centralized and ignoring the special condition in Papua. The policy implemented in Papua is not just ignore welfare aspect in Papua, but also deny the basic right of native communities and also reality of opinion difference concerns the history of Papua unitary with various of problem faced. Efforts that ever conducted is assessed less touching the source of problem and Papuan aspiration so it triggering frustration and dissatisfaction.

As background on the establishment of Special Autonomy Act for Papua it can be known that the purpose of Special Autonomy is to resolve the source of problem in Papua as the aspiration of Papua peoples. However, the substance of Special Autonomy Act for Papua itself does not include efforts to solve the source of problem in Papua. The Special Autonomy Act for Papua can only be used as a normative instrument for review to the source of problem such as "gaps, equal opportunities, as well as the protection of basic rights and basic human rights."

Specifically, the Special Autonomy Act for Papua states that the purpose of Papua Special Autonomy is to reducing the gap between Papua with other province; improve the living standard of communities in Papua, as well as providing opportunities addressed to the native people of Papua. ${ }^{2}$ Basic values which was used as a foothold the enforcement of Special Autonomy is protection and respect against the ethics and morals, basic rights of native people, human rights, law supremacy, democracy, pluralism, and equal status, rights and obligation as citizens. Thus, the autonomy given to Papua is special and different to the autonomy that implemented in other region. Therefore, should the pro-

\footnotetext{
Institute for Local Development. (2005). Pasang Surut Otonomi Daerah: Sketsa Perjalanan 100 Tahun. Jakarta: Yayasan TIFA, p. 28.
} 
vision of local autonomy and local government as implemented in Papua is also different with other region in Indonesia.

From two region were given special autonomy in Indonesia, namely Papua and Aceh, Aceh can be said to have succeeded, but not so with Papua. Aceh has been able to minimize conflict and armed violence and run the government in good, although there is small violence. This differs from Papua are still conflict and often violence. Certainly, there are many factors that contribute to differences in both regions.

The fundamental difference between Aceh and Papua is in terms of conflict resolution. In Aceh, the conflict of separation politic is completed before the implementation of Special Autonomy. Special autonomy in Aceh is an agreement product altogether of the parties involved in the conflict so that implementation was conceived together as a follow up to resolve conflicts. This is in contrast to what happened in Papua. Papua Special Autonomy cannot be said to be a form of collective agreement, but rather a product of the central government to reduce the conflict in Papua. If the Special Autonomy of Aceh is a follow up of conflict resolution, the Special Autonomy of Papua was conducted in an attempt to resolve the conflict. Consequently, there is no common understanding of the parties involved in the conflict to the existence of special autonomy. For the central government, the Special Autonomy is a tangible manifestation of efforts to resolve the conflict, while for some people of Papua Special Autonomy is the creation of the central government to stop their resistance.
The implementation of special autonomy during 16 years in Papua needs to be reviewed. Therefore, should be assumed that the performance of the Special Autonomy for Papua demonstrates the high level of community dissatisfaction with the implementation of the Special Autonomy for Papua. Even mentioned to the some cases of Special Autonomy is actually increase public distrust of the government. ${ }^{3}$ Some reasons for the failure of Special Autonomy for Papua, includes: some substances in the Special Autonomy Act which raises unresolved conflict between the Papua people and the central government, such as the problem of emblem and region flag. Although the presence of emblem and flag are recognized in Article 2 paragraph (2) of Act No. 21 of 2001 but did not get further formulation and in fact hindered by the government. The case of the raising of Bintang Kejora flag is a common example. Armed force and police reject to raising Bintang Kejora flag.

In its implementation, the political dimension in the resolution of problem in Papua is stronger than the development and improvement of well-being. Special Autonomy is more filled by political events such as the expansion return the Special Autonomy to the local elections. Very little space is available for concrete programs to improve the lives of Papua people in order to eliminate the gap between the center and Papua, other region and Papua, even between Papuans and migrants.

The rules of Special Autonomy does not run as fast as the disbursement of Spe-

\footnotetext{
Agung Djojosoekarto (eds.). (2008). Kinerja Otonomi Khusus Papua. Jakarta: Kemitraan Bagi Pembaruan Tata Pemerintahan di Indonesia, p. 41.
} 
cial Autonomy. Consequently, no one can guarantee the regulatory framework of special autonomy fund flows for development to improve peoples' lives. Instead, the Special Autonomy funds many suspected corruption or used for the benefit of the elite in Papua. Therefore, evaluation of the Special Autonomy should be done every year after the first evaluation in the third year as mandated Special Autonomy Act was not done in-depth and comprehensive. As a result, people never get a portrait of the Special Autonomy in the enjoyment of their fundamental rights as a whole.

Last but not least, in the aspect of socialization on communities. Special Autonomy is informed to the wider public but not well-informed. Peoples know about the special autonomy but do not understand it thoroughly. With such reality, the Special Autonomy operates to be a policy that is not participatory. Policy that operated by a single perspective of the government.

In general should be assumed that the performance of special autonomy for ten years of implementation has yet to reach the expected performance. One official statement is considered significant as an indicator of the low performance of Special Autonomy is the statement of the former Governor Barnabas Suebu ${ }^{4}$ that poor household in Papua, there were 480.578 or equal to $81.52 \%$ of the total households. This figure is approximately equivalent to $72.72 \%$ indigenous Papuans as poor levels, even absolute poor.

The failure of Special Autonomy can also be seen from the implementation of spe4 Barnabas Suebu, Harian Cenderawasih Pos, Jayapura, 2014, page. 8 . cial autonomy is not matched by efforts to resolve the political conflict peacefully. This resulted in "politicizing" the implementation of special autonomy either by the central government as well as by groups in Papua peoples. Special Autonomy shifted to politics issues, not a real program to improve living standards and respect the basic rights of Papua people in accordance with the background of the special autonomy itself. The central government is still using a security approach that is diametrically opposed to special autonomy to improve respect for human rights. ${ }^{5}$

Protection of indigenous rights has expressly provided in Article 43 paragraph (1) Special Autonomy Act for Papua, that: "the Government of Papua Province shall recognize, respect, protect, empower and develop the rights of indigenous peoples to be guided by the provisions of legal regulations apply." The government's obligation referred to in paragraph (1) is also an obligation of government implemented by the Governor as representative of the government. Empowerment certain rights include coaching and development aimed at improving the living standards of good physically and mentally indigenous peoples.

The rights of indigenous peoples include collective rights as citizens, known as customary rights and the rights of individual of customary law. Customary rights are collective rights of indigenous people concerned. The subject of customary rights is certain customary law peoples, not individuals, and also not a traditional ruler, although many of them have served for generations.

William Liddle. (2005). Revolusi Dari Luar: Demokratisasi di Indonesia. Jakarta: Nalar, p. 63. 
Indigenous ruler is customary right implementer as officer of a customary law people to manage customary rights in the region. Customary rights are governed by certain customary law in customary law people concerned. The reality today is the existence of customary rights of indigenous law peoples are diverse, with regard to social and economic development of the customary law people either under the influence of internal and their environment.

The power of indigenous traditions to influence the national legal system cannot be ignored. ${ }^{6}$ Then, indigenous rights is recognized by the national land law along by the fact still exist. Utilization of customary rights in the interests of the government and/or private is done through consultation between indigenous peoples and those who need to be accompanied by compensation in the form of cash, replacement land, resettlement, or any other form agreed. The government of Provincial, District/Municipal as the institution most know the dispute things that happened in the region is obliged to active mediation in resolving disputes that arise between customary law peoples or citizens by the other party. Disputes between customary law peoples itself is resolved through traditional justice. In relation to the protection of indigenous peoples' rights to land, in Article 26 the Declaration on the Rights of Indigenous Peoples, also determine the rights of indigenous peoples to their lands, territories and resources which they have traditionally, lived or otherwise used or acquired.

Stephen Muecke. (2011). "Australian Indigenous Philosophy." CLCWeb: Comparative Literature and Culture 13(2): 1-7. Doi: http://dx.doi.org/10.7771/1481$\underline{4374.1741}$
A main problems faced during this in Papua is the violation of indigenous rights of Papuans. Especially the violation of the rights of indigenous Papuans in relation to the exploitation of natural resources, traditional technologies of indigenous people. Customary rights include individual right and collective rights (customary rights) on land, water or sea at certain boundaries, as well as forest and the natural riches contained therein. This situation is one of the main factors causing a variety of social inequality and even resistance shown by Papua people are not uncommon with weapon violence by state officials.

\section{ANALYSIS AND DISCUSSION}

\section{Indigenous Peoples and the Rule of Customary Law}

Customs have strong and influence ties in society. The binding strength depends on the community that supports the custom, especially foundation on the feeling of togetherness, idealism and justice. It is hard to imagine that the customs although maintained continuously, by itself will realize legal certainty. Legal certainty can only be realized if there are binding rules that govern the lives of the present and the future.

Historically, the use of the term "customary law" in Indonesia first expressed by Snouck Hurgronje with the term "Adatrecht" based on the results of his research on the people of Aceh. The term Adatrecht was inspired by the terms of Customary Law encountered in the study. Later the term became popular among the Dutch colonial

\footnotetext{
Moh. Koesnoe. (1996), Hukum Adat; dalam Alam Kemerdekaan Nasional dan Soalnya Menghadapi Era Globalisasi. Surabaya: Ubhara Press, pages. 36-38
} 
administration and the Bachelor of Laws after being introduced by van Volenhoven. In Indonesia, the use of the term customary law has existed since 1948 in the Indonesian youth congress, and in 1948 introduced among academics in Indonesia by Supomo. ${ }^{8}$

Van Vollenhoven suggested that the notion of custom is having penalties, while Ter Haar, ${ }^{9}$ is famous with beslissingenleer seeing customary as what is set forth in the decisions that have a structural relationship with values and social order from the customs authorities. Seminar results of customary law held on the cooperation between the National Law Development Agency with the Faculty of Law, Gadjah Mada University on 15-17 January 1975 to formulate, customary law. As an original Indonesian law is not written in the form of laws of the Republic of Indonesia contains an element of religion.

The views of experts above, substantially provide an understanding that custom is law that always live and thrive in a society, which always follows the development of era, providing a guarantee for the public order, as well as capable of delivering justice. Customary law aims to create peace and promote prosperity for the citizens. In connection with this study, then in essence, all policies land management aims to provide assurance that the resources of land and nature are used effectively and efficiently, in order to support social and economic development in a sustainable manner, protecting the land, natural resources and residential areas of damage or use unintended, and sup-

Ter Haar. (2001). Asas-Asas dan Susunan Hukum Adat. (Translated by: Soebakti Poespono). Jakarta: Pradnya Paramita. p. 3.
}

porting decentralization, effectiveness and accountability of government.

The term indigenous peoples are often equated with the term customary law peoples. Some experts distinguish the use of terms, which of course the definition is influenced by the views and their backgrounds. The term "masyarakat adat" is the translation of the word indigenous peoples (English), ${ }^{10}$ which is distinguished in terms of customary law people which is a translation of the term rechtgemencshap (Dutch). Consideration use the term indigenous peoples is considered a broader meaning than the term customary law peoples that ultimately only will narrow the entity of indigenous peoples, which is limited to legal entities. The term indigenous peoples are believed to have a broad meaning dimension than just the legal aspect, in terms of the indigenous people is closely linked to the cultural dimension, religion and so forth.

In Indonesia, the term indigenous peoples have not translated into "native people", but rather to "indigenous peoples". The use of the term indigenous peoples can generate sharp polemics may even be a source of conflict. While the use of the term indigenous peoples, in terms of use, is considered more popular. Although the term "indigenous peoples" translated by masyarakat adat, but the definition of indigenous peoples is very similar to the general definition of indigenous peoples. In Masyarakat Adat Nusantara I held in March 1999, it was agreed that indigenous peoples are groups of people who

\footnotetext{
10 In English Indigenous People means a group of people/ community who has individual rights, while Indigenous Peoples refers to a group of people/community who has collective rights.
} 
have origins ancestors (hereditary) in a certain geographic area, and has a value system, ideology, economic, political, cultural, social and own territory. ${ }^{11}$ While, the ILO 169 Convention of 1989 concerning Indigenous and Tribal Peoples in Independent States defines indigenous peoples as tribes who resided in independent countries whose social, cultural, and economic contrast to other communities. Or, tribes that inhabited a country since colonization and it have economic institutional, culture and politics itself. ${ }^{12}$

As comparison, in other countries, many of the terms used, for example, first peoples among anthropologists and defender/supporter, first nation in the United States and Canada, indigenous cultural communities in Philippines, bangsa asal and orang asli in Malaysia. While, the UN has agreed to the use of the term indigenous peoples as contained in the entire document discusses one of the draft United Nations' declaration, the draft of the LW Declaration on the Rights of the Indigenous Peoples. ${ }^{13}$

Differences in terminology meaning are also reflected in the use of the term "law community" and "customary law community" specifically both terms is a different understanding. Kusumadi Pujosewojo interprets the law community as a community who set, bound and subject to its own legal system. While customary law commu-

11 See, Keputusan Kongres Masyarakat Adat Nusantara (AMAN) Kep. KMAN No: 01/KMAN/1999.

12 Ricardo Simarmata. Menyongsong Berakhrnya Abad Masyarakat Adat: Resistensi Pengakuan Bersyarakat. (Paper) Presented on "Pelatihan Pengelolaan Lingkungan Hidup Daerah". Pusat Penelitian Lingkungan Hidup, Institut Pertanian Bogor, July 5, 2002, p. 2.

13 Sandra Moniaga. (2002). "Hak-hak Masyarakat Adat dan Masalah serta Kelestarian Lingkungan Hidup di Indonesia". Jurnal WACANA HAM, Media Pemajuan Hak Asasi Manusia, 10(2): 1-14. nity is a society that arise spontaneously in a particular region, the establishment is not stipulated or ordered by higher authorities or other authorities, with a sense of solidarity is very big among the members, looking not a member of the community as an outsider and use its territory as a source of wealth which can only be fully utilized by members. ${ }^{14}$ Hence, in the context of this paper used the term customary law community, considering that besides being a term that has been commonly used in customary law, also have characteristics in a comprehensive study of the science of law. While understanding the customary law community is a group of people who are bound by customary legal order as citizens shared a partnership of law because of the similarity residence or on the basis of descent.

Furthermore, a study on "Customary Rights", historically the origin of the conception of customary rights rooted in the cultural aspects of the Malay society that has foundations in the community in question at the time. Conceptually, customary rights are solely owned by the clan community, and the clan community comes from people who are applying unilateral kinship (a joint system between matrilineal with patrilineal system). The foundations of kinship are then led to the definition of "customary rights". In extensive sense, customary rights land is essentially serves as a guarantee of the common welfare, source of tax needs, and as a source of funds to organize a celebration of custom (customary claim). Thus, the definition of customary rights under customary

\footnotetext{
14 Maria S. W. Sumardjono. (2009). Tanah Dalam Perspektif Hak Ekonomi, Sosial dan Budaya. Jakarta: Buku Kompas, p. 56.
} 
law conception is a right held by clan/relatives of indigenous peoples in a unit of customary law.

A society based on the principles of heredity members feel bound in an order based on the belief that they all come from the same lineage. In customary law communities there are three kinds of affinity which, according to the male line (patrilineal), a line of women (matrilineal) and the combined mother and father (parental). ${ }^{15}$ In Indonesia, there are two types of foundation uniting people based on descent, which in Dutch is called altenerend and dubbelunilateraal. Basic Agrarian Law (BAL) uses the term customary rights (region) to show the land is an area of environmental law community concerned. BAL recognizes the existence of indigenous people and their customary rights. Recognition of customary rights carried along by the fact still there, is not contrary to the national interest and must not conflict with the higher laws and regulations.

In practice, customary law does not give the name of the term customary, but only to show the territory land as belonging. In some regions used the term pertuanan in Ambon (territory land as belonging), panyampeto in Kalimantan (a place that giving feed), pewatasan in Kalimantan, wewengkon in Java, prabumian in Bali (as a restricted area), or as forbidden land to others, for example, tatabuan-Bolaang in Mongondow. It is also known in some areas of land almost the same as torlok-Angkola, limpo-South Sulawesi, Muru-Buru, Payar-Bali, paerLombok and ulayat Minangkabau. ${ }^{16}$ The use of different terms that cannot be separated 15 Ter Haar, Op.Cit, p. 9.

$16 \quad$ Ibid. p. 68. from the customary laws applied in their respective areas in Indonesia, because basically customary rights are part of customary law, and is the highest tenure on land in customary law.

Accordingly, to mention customary rights, van Vollenhoven uses the term beschikkingsrecht. ${ }^{17}$ Customary rights is a very old right covering the entire Indonesia that the origin of a religious nature. These rights are owned by a tribe (stam), or by a combination of the village (dropsbond) or usually by a village only, but never owned by an individual person. ${ }^{18}$

\section{Historical Overview for Special Autonomy}

The relationship of Papua with the archipelago has existed since long. Harsya W. Bachtiar ${ }^{19}$ stated that at the beginning of the eighth century already exist relationship between these regions, as evidenced in the era of King Hayam Wuruk with Maha Patih Gadjah Mada (the $13^{\text {th }}$ century) which requires some area of Papua as part of the archipelago. Around the sixteenth century, Europeans began to enter the Papua territory, even the designation of Papua to the natives is given by Jorge de Menezes, the Portuguese governor in Ternate. He called the region as "Ilhas dos Papuas". The word Papua itself according to Stirling is derived from the word Malay "pua-pua" which means "curly". ${ }^{20}$

\footnotetext{
17 Boedi Harsono. (2003). Hukum Agraria Nasional, Sejarah Pembentukan Undang-Undang Pokok Agraria, Isi dan Pelaksanaannya. Jakarta: Jambatan, p. 186.

18 Van Vollenhoven. (1956). Ichtisar Lengkap De Indonesia en zijn ground jilid 1. (Translated by: Soewargono). Yogyakarta: Yayasan Badan Penerbit Gadjah Mada, pages. 16-17.

19 Agus Sumule. (2003). Mencari Jalan Tengah: Otonomi Khusus Provinsi Papua. Jakarta: PT. Gramedia, p. 6.

20 Koentjoroningrat. (1994). Irian Jaya Membangun Masyarakat Mejemuk. Jakarta: Djambatan, pages. 44-45.
} 
In 1898, the Dutch began ruled Papua by dividing the area of Papua into 2 (two) region, the northern part is called Afdeeling Noord Niew-Guinea, and the western and southern parts are called Afdeeling Westenzuid Niew-Guinea, each is headed by a controller Netherlands with domicile in Manokwari and Fak-Fak. The both area was a subsection of karisidenan Maluku. ${ }^{21}$

After the declaration of Indonesian independence on 17 August 1945, Papua included in the Unitary State of the Republic of Indonesia. This region is one karisidenan located in Maluku province. Its resident domiciled in Ambon, because the Dutch still control the territory. The name of Papua is replaced Irian by Indonesia, since the name of Papua is regarded demeaning the native population. ${ }^{22}$ But over time, the demands of Papua Merdeka intensified. In fact, the flag of OPM Bintang Kejora in entire Papua. The claim is even delivered directly by 100 Papua leaders in dialogue with President BJ. Habibie on 26 February 1999 at Merdeka Palace, Jakarta. ${ }^{23}$

Responding to the demands of Papua Merdeka, in October 1999 the new government that elected through the peoples' representatives in the People Consultative Assembly stipulates a special autonomy for the province of Irian Jaya. Finally, after a fierce discussion and protracted in the Parliament, on 20 October this draft legislation approved by the Parliament, and dated 21 November 2001, signed by President Megawati Soekarno Putri.

${ }_{21} \quad$ Ibid, p. 53.

22 Ibid, pages. 72-76.

23 Frans Maniagasi. (2001). Masa Depan Papua: Merdeka, Otonomi Khusus dan Dialog. Jakarta: Milinium Publisher, p. 33.
The problem that motivate the birth of the special autonomy for Papua Province according Assistance Team of Papua Special Autonomy $^{24}$ has not been successful came from the central government to provide welfare, prosperity, and recognition to the basic rights of Papuan. Conditions of Papuan in the fields of education, economy, culture and social politics still poor. In fact, some of them still live like in ancient era. In addition, fundamental problem such as human rights violation and denial of the rights of people's welfare in Papua is still not resolved in fairly and dignity. ${ }^{25}$ This situation has resulted in a variety of dissatisfaction in throughout Papua and expressed in various forms.

Viewed from the problem in policy of Papua Special Autonomy No. 21 of 2001, as has been described above, then the policy target in not far from the problems faced by Papuan and the wishes of Papuan, among others, improving the welfare of Papuan, respect for civil rights and human rights/ basic people of Papua, the freedom to manage household itself, as well as fair distribution of natural products for the Papuan.

Thus, it is clear that the special autonomy for Papua Province is basically giving wider powers to the province and Papua people to organize and take care of themselves in the framework of the Unitary Republic of Indonesia. Greater authority also mean greater responsibility for the province and the people of Papua to govern and regulate the use of natural resources in Papua province to for the greater prosperity of the people of Papua as part of the people of Indonesia in accordance with the legislation. This

${ }_{24}$ Agus Sumule, Op.Cit, pages. 39-40

25 Frans Maniagasi, Op.Cit, p. 65 
authority also means authority to empower the socio-cultural and economic potential of the people of Papua, including providing adequate role for the indigenous people of Papua through the representatives of customs, religions and women. On that basis, it can be concluded that ideally granting special autonomy for Papua Province is intended to bring about justice, uphold the rule of law, respect for human rights, accelerating economic development, improving the welfare and progress of the people of Papua, in the framework of equality and balance with the progress of another province.

\section{Recognition and Protection of Indigenous Peoples on Land}

For indigenous peoples, land and nature (natural resources) has a very special meaning as a form of existence, socio-cultural roots, symbol of existence and socio-economic status. Even had a religious significance that cannot be separated between man and land. Therefore, the protection of indigenous peoples' rights to land are not just running a formal mechanism of a legal rule, but more than that, striving for the realization of the values embodied in the rule of law. Conception of protection and law enforcement lead to the harmonious relationship between the values contained in the rule of law and the values that live in the community.

As described earlier that the protection of indigenous peoples' rights to land have been set out clearly in Article 43 on Special Autonomy for Papua. The rights of indigenous peoples includes customary rights of indigenous communities, the individual right of citizens concerned the implementa- tion of indigenous customary rights along by the fact still exist. The government of Papua Province shall recognize, respect, protect, empower and develop the rights of indigenous peoples based on the provisions of existing laws. Therefore, the provision of customary land and individual land of citizens for the benefit of any customary law is done through consultation with indigenous people and their concerned citizens to opportunities regarding the delivery of the necessary land or compensation.

Further arrangement of the protection of indigenous rights to land is evident in the form of Special Local Regulation, Perdasus -referred to the Indonesian legal literature as 'Peraturan Daerah Khusus'- Papua Province No. 23 of 2008 on Customary Rights of Indigenous People and Individual Rights of Indigenous Law People on land. The birth of Perdasus by consideration that customary right of customary law communities and or individual rights of indigenous law communities on land have limitations and so far its use has caused environmental degradation, Inequality structure ruler, possession and use, the lack of capacity of the environment, increased conflict and less attention to the interests of indigenous/local people and other vulnerable groups.

The existence of customary right of customary law community and individual rights of customary law community on land are given for research in district/cities in the area. Research to determine the presence or absence of customary right of customary law community and/or the individual right of customary law community on land carried out by a committee of researchers consist- 
ing of experts in customary laws, customary institutions or custom ruler who authorities over customary rights or individual rights of customary law community concerned, nongovernmental organizations, officials from the National Land Agency of the Republic of Indonesia, officials from the Office of the Legal Division of Regents/Mayors and officials from other relevant institutions.

Recognition of customary rights by customary law community is intended that the customary law citizens can obtain the prosperity and welfare of the highest order. Therefore, customs authorities are authorized to carry out the management of customary rights is obliged to utilize customary rights for the benefit of its citizens through joint efforts of citizens or in cooperation with other parties. Where, for the purposes of public interest required the release of community land rights of indigenous and or individual right people on land then the public holders of customary rights and or individual customary law obliged to release lands which required the provision of compensation for the physical factors and compensation factors of non-physical reasonable according to the agreement between the government and indigenous people and their individual citizens or indigenous people and to pay attention to the ability of government finances.

With the management of customary right of customary law community and/ or individual right of customary law community on land, customary law community concerned must comply with the legislation in force. For example, if some areas of customary right of customary law community and/or the individual right of customary law community on land included protected forest, or a wildlife or other protected areas, the customary law community and individual right must preventing damage and not allowed to be given to peoples or to the other party for the purposes of cultivation.

\section{Horizontal Conflicts related to Ownership of Customary Community Rights on Land} The main problem of land sourced from the legal aspect, whether regulatory, institutional and enforcement. For example, the fundamental values of ideology of Pancasila as philosophische grondslag and the 1945 Constitution such as morale, justice, equality, and human rights, not elaborate in hierarchy, pure and consistent in agrarian legislation (particularly with regard to customary rights) follows the implementing regulations under it. Even the arrangement of customary rights of customary law community or individual in the special autonomy law is inadequate.

Furthermore, the elaboration of the constitutional rights of customary law community in the agrarian law is biased due to sectoralism of laws related to agrarian. Agrarian law does have some weaknesses, as well as with the Special Autonomy Law for Papua, such as the lack of a clear to regulates human rights, land rights, forestry sector, mining, spatial planning and the environment. As a result, any sectoral laws include regulations on indigenous peoples in the interests of the individual and leads to a horizontal conflict between indigenous peoples and third parties. Sectoralism has put indigenous peoples who are exploited as objects rather than as subjects that must be 
met for their rights in the economic, political, social, cultural, and ideological.

The arrangement of the indigenous peoples in sectoral put these people in a helpless position. Implementation of the right to control the State through sectoral laws give permission for companies to exploit natural resources in indigenous regions claimed. ${ }^{26}$ Licensed by the state substantially means giving legal rights of exploitation to entrepreneurs or investors. Legal rights such as concessions in forestry and work contract in mining sector is principally contradict with the concept of indigenous peoples' rights to land and natural resources. Such a situation has led to a bloody conflict, both among fellow citizens of indigenous peoples over land estates and mines in Mimika, Nabire and a few other places in the province of Papua.

The results of research and empirical reality on the field proves that there have been irregularities in the management of customary rights by customary law community and/or individual right on the protected forest area or a wildlife or other protected areas such as in Skylen South Jayapura and protected areas Kampung Harapan. Where it occurs because the customary land management permit communities that issued by tribe chief or Ondoafi to third parties for investment activities.

After the enactment of Act No. 21 of 2001 on Special Autonomy for Papua Province and Special Regional Regulation of Papua (Perdasus) No. 23 of 2008 on customary rights of customary law community on

26 Ahsan Yunus, Frans Reumi, Irwansyah. (2015). "Recognition of the Customary Court: A Review of Decentralization in Papua as Special Autonomy". Journal of Research in Humanities and Social Science, 3(7), 5769. land has put customary law community and/ or individual as development subjects rather than objects of development. Primarily, related investments in the district/city. Recognition and respect for customary right of customary law community and/or individual are framed in Act No. 21 of 2001 and Perdasus No. 23 of 2008 does not necessarily give space for re-possession the land plots of excustomary rights already owned by communities outside the communion of customary law with the argument or for any reason, let alone contrary to the provisions of the legislation in force.

A further factor is imbalance of land ownership and natural resources. This is because there is no legislation as a solid legal basis to set the minimum and maximum boundaries/land rights, both individuals and institutions. For example, the maximum boundaries of ownership and so on. As a result, the more number of small farmers, tenant farmers, because their land has been taken for public use, was purchased by a private company at an amazing price, converted, and so on. Instead, there is an entrepreneur who has millions of hectares of farmland, forest and mining production that occurs for land plots of customary rights of customary law community and/or individual.

Observing typology horizontal conflicts that occurred after the implementation of Papua Special Autonomy, then in prevention, managing, and completion of the National Land Agency is coordinating with relevant agencies. There are at least 2 (two) categories: First, relevant departments, such as the Forestry, Agriculture, Transmigration and SOEs. Second, law enforcement agen- 
cies, such as police, prosecutors, the judiciary and the judicial commission.

\section{CONCLUSION}

Recognition and protection of the land rights of indigenous peoples have been set clearly in the national legal system, such as Agrarian Law, Forest Law, as well as in Mineral and Coal Mining Law. However, recognition and protection of indigenous peoples' rights to land in various legal products is still ambivalent. The essence of protection of indigenous peoples' rights to land is also clearly regulated in Act No. 21 of 2001 and Perdasus No. 23 of 2008 has put customary law community on ownership of communal land is not the object of development, especially in the field of investment. Recognition and protection of indigenous people' right to their communal land does not necessarily give space for re-possession the land plots of ex-customary rights already owned by communities outside the communion of customary law with the argument or for any reason, let alone contrary to the provisions of the legislation in force.

As a recommendation, the customary right and indigenous land which is the property and become an authority on indigenous peoples must be recognized by the government and regional and national communities about its presence. Therefore, the government should strive to protect the customary right through regulation of the Ministry of Agrarian and Land Agency and other laws related to the issue of customary rights, customary lands, indigenous peoples and their authority. In the aspect of local government, district/municipal governments needs to regulate the implementation of Article 43 of Act No. 21 of 2001 and Perdasus No. 23 of 2008 concerning local regulation in order to provide maximum legal protection against indigenous peoples to their communal land.

\section{BIBLIOGRAPHY}

Agung Djojosoekarto (eds.). (2008). Kinerja Otonomi Khusus Papua. Jakarta: Kemitraan Bagi Pembaruan Tata Pemerintahan di Indonesia.

Agus Sumule. (2003). Mencari Jalan Tengah: Otonomi Khusus Provinsi Papua. Jakarta: PT. Gramedia.

Ahsan Yunus, Frans Reumi, Irwansyah. (2015). "Recognition of the Customary Court: A Review of Decentralization in Papua as Special Autonomy". Journal of Research in Humanities and Social Science, 3(7), 57-69.

Barnabas Suebu, Harian Cenderawasih Pos, Jayapura, 2014.

Boedi Harsono. (2003). Hukum Agraria Nasional, Sejarah Pembentukan UndangUndang Pokok Agraria, Isi dan Pelaksanaannya. Jakarta: Jambatan.

Frans Maniagasi. (2001). Masa Depan Papua: Merdeka, Otonomi Khusus dan Dialog. Jakarta: Milinium Publisher.

Institute for Local Development. (2005). Pasang Surut Otonomi Daerah: Sketsa Perjalanan 100 Tahun. Jakarta: Yayasan TIFA.

Koentjoroningrat. (1994). Irian Jaya Membangun Masyarakat Mejemuk. Jakarta: Djambatan.

Maria S. W. Sumardjono. (2009). Tanah Dalam Perspektif Hak Ekonomi, Sosial dan Budaya. Jakarta: Buku Kompas. 
Moh. Koesnoe. (1996), Hukum Adat; dalam Alam Kemerdekaan Nasional dan Soalnya Menghadapi Era Globalisasi. Surabaya: Ubhara Press.

Ricardo Simarmata. Menyongsong Berakhrnya Abad Masyarakat Adat: Resistensi Pengakuan Bersyarakat. (Paper) Presented on "Pelatihan Pengelolaan Lingkungan Hidup Daerah". Pusat Penelitian Lingkungan Hidup, Institut Pertanian Bogor, July 5, 2002.

Sandra Moniaga. (2002). "Hak-hak Masyarakat Adat dan Masalah serta Kelestarian Lingkungan Hidup di Indonesia”. Jurnal WACANA HAM, Media Pemajuan Hak Asasi Manusia, 10(2): 1-14.
Stephen Muecke. (2011). “Australian Indigenous Philosophy." CLCWeb: Comparative Literature and Culture 13(2): 1-7. Doi: http://dx.doi.org/10.7771/1481$\underline{4374.1741}$

Ter Haar. (2001). Asas-ssas dan Susunan Hukum Adat. (Translated by: Soebakti Poespono). Jakarta: Pradnya Paramita.

Van Vollenhoven. (1956). Ichtisar Lengkap De Indonesia en zijn ground jilid 1. (Translated by: Soewargono). Yogyakarta: Yayasan Badan Penerbit Gadjah Mada.

William Liddle. (2005). Revolusi Dari Luar: Demokratisasi di Indonesia. Jakarta: Nalar. 